\title{
UPAYA PENINGKATAN GIZI BALITA DENGAN PEMBERIAN MAKANAN TAMBAHAN (PMT) BERKUALITAS DI DESA PANGKUR, KEC.PANGKUR, KABUPATEN NGAWI
}

\author{
Toddler Nutrition Improvement Efforts With Additional Quality Food (PMT) \\ In Pangkur Village, Kec. Pangkur, Ngawi District
}

\author{
Erwin Kurniasih ${ }^{1}$, Edy Prawoto $^{2}$, Pariyem $^{3}$ \\ Dosen Akademi Keperawatan Pemkab Ngawi
}

\begin{abstract}
Abstrak
Gizi buruk atau kurang di Indonesia masih menjadi permasalahan yang perlu mendapat perhatian dari berbagai pihak baik pemerintah, tenaga kesehatan, maupun masyarakat. Salah satu upaya untuk mengatasi gizi kurang atau buruk pada balita adalah dengan pemberian makanan tambahan (PMT) yang berkualitas. Sebagai tenaga kesehatan, tim pengabdi peduli untuk membantu menangani masalah gizi balita yang terjadi di masyarakat dengan melaksanakan kegiatan pemberian PMT berkualitas pada balita. Bentuk kegiatan yang dilakukan adalah penilaian status gizi balita dengan pendataan usia balita, menimbang dan mengukur tinggi badan. Selain itu juga dilakukan penyuluhan tentang PMT balita yang diakhiri dengan pembagian PMT bagi balita. Kegiatan ini dilakukan pada tanggal 9 April 2018 di Posyandu balita desa Pangkur, kec.Pangkur kota Ngawi. Jumlah balita yang hadir 42 anak. Dari hasil kegiatan, didapatkan data untuk status gizi balita baik sebanyak 34 anak (81\%), gizi kurang 8 anak (19\%), dan tidak ada gizi buruk.
\end{abstract}

Kata Kunci : Balita, Gizi, PMT

\section{PENDAHULUAN}

Status gizi balita yang baik memegang peranan penting dalam pertumbuhan dan perkembangan terutama pada tahap golden period di lima tahun pertama. Upaya perbaikan status gizi balita dapat memberikan kontribusi bagi tercapainya tujuan pembangunan nasional terutama dalam hal penurunan prevalensi gizi kurang pada balita yang pada akhirnya akan dapat meningkatkan kualitas sumberdaya manusia. Status gizi balita yang buruk dapat membawa dampak negatif terhadap pertumbuhan fisik maupun mental, penurunan daya tahan tubuh, serta dampak yang lebih serius adalah timbulnya kecacatan, tingginya angka kesakitan dan percepatan kematian (Ali, 2006; Mamhidira, 2006; Andriani, 2012).

Data dari Riset Kesehatan Dasar (Riskesdas) tahun 2013 menunjukkan prevalensi balita kurus dan prevalensi balita stunting masing-masing sebesar 12,1\% dan 37,2 \% (Kemenkes RI, 2017). Hasil Pemantauan Status Gizi (PSG) tahun 2017 di Indoonesia menujukkan prevalensi stunting pada balita sebesar $27,5 \%$, balita kurus $8,0 \%$, balita sangat kurus $3,1 \%$, balita risiko kurus $22,8 \%$, dan balita dengan gizi kurang sebanyak 17,8\% (Direktorat Gizi Masyarakat Kemenkes RI, 2017). Fakta ini menunjukkan masalah gizi balita masih menjadi perlu mendapat perhatian.

Pemberian makanan tambahan (PMT) khususnya bagi kelompok rawan merupakan strategi suplementasi dalam mengatasi masalah gizi. PMT yang diberikan harus berkualitas dan disesuaikan tahapan usia pertumbuhan. PMT dapat diberikan mulai usia 6-59 bulan dengan memenuhi syarat khusus tentang jumlah zat gizi yang diperlukan bayi seperti protein, energi, lemak, vitamin, dan mineral. Di Kabupaten Ngawi Pemerintah Daerah melalui Dinas Kesehatan Kabupaten Ngawi telah melaksanakan program gerakan tuntas gizi buruk (Restu Ibu) sehingga balita gizi buruk yang ada dapat diberikan penanganan agar status gizinya dapat meningkat menjadi lebih baik. Program tersebut sudah mampu menurunkan angka balita dengan status kurang gizi, namun demikian cakupannya belum mencapai $100 \%$ karena masih terdapat balita dengan gizi kurang atau buruk. Hal ini dikarenakan masih banyak orang tua balita yang belum memahami bagaimana 
memberikan PMT yang tepat sehingga masyarakat perlu mendapat wawasan tentang penyediaan PMT yang sesuai untuk balita sesuai dengan tahap pertumbuhannya.

Sebagai dosen dan tenaga kesehatan yang ikut bertanggung jawab terhadap kesehatan masyarakat, tim pengusul peduli dan termotivasi untuk ikut serta dalam meningkatkan status gizi balita sehingga dapat menurunkan kejadian balita gizi buruk atau kurang. Upaya ini dilakukan melalui kegiatan pengabdian masyarakat yaitu pemberian makanan tambahan bagi balita usia 6-59 bulan.

\section{METODE PELAKSANAAN}

Kegiatan pengabdian ini dilakukan bersamaan kegiatan Posyandu balita di Desa Pangkur dengan cara menimbang balita, memberikan penyuluhan pada orang tua/pengasuh balita, dan pemberian PMT. Balita yang datang langsung dilakukan pendataan terkait nama dan usia, kemudian diukur dan ditimbang berat badannya. Setelah itu itu dikumpulkan bersama orang tua untuk diberikan penyuluhan tentang PMT yang berkualitas dan cara penyiapan, serta pengolahan yang benar. Kegiatan diakhiri dengan pembagian PMT dimana setiap balita akan menerima satu paket PMT.

Kegiatan ini dilaksanakan pada hari Rabu, tanggal 9 April 2018. Lokasi kegiatan dilakukan di Posyandu Balita, Desa Pangkur, Kec.Pangkur, Ngawi.

\section{HASIL DAN PEMBAHASAN}

Kegiatan pengabdian masyarakat dalam rangka pemberian peningkatan gizi melalui PMT telah dilakukan pada 42 balita di Posyandu balita Desa Pangkur, Kec. Pangkur, Kabupaten Ngawi. Balita yang hadir dalam rentang usia 1-59 bulan dengan rincian laki-laki sebanyak 17 dan perempuan sebanyak 25 .

Hasil penilaian status gizi balita dalam kegiatan pengabdian masyarakat digambarkan dalam tabel 1 berikut ini.

Tabel 1. Hasil pendataan dan status gizi balita di Posyandu Desa Pangkur, Kecamatan Ngawi bulan April tahun 2018

\begin{tabular}{ccccc}
\hline \multirow{2}{*}{$\begin{array}{c}\text { Usia } \\
\text { (bln) }\end{array}$} & \multicolumn{3}{c}{ Status gizi balita } & \multirow{2}{*}{ Jumlah } \\
\cline { 2 - 5 } & Baik & Kurang & Buruk & \\
\hline $0-6$ & 6 & - & - & 6 \\
\hline $6,1-12$ & 4 & - & - & 4 \\
\hline $13-24$ & 8 & 4 & - & 12 \\
\hline $25-36$ & 8 & - & - & 8 \\
\hline $47-48$ & 4 & 2 & - & 6 \\
\hline $49-60$ & 4 & 2 & - & 6 \\
\hline $\begin{array}{c}\text { Jumlah } \\
\text { total }\end{array}$ & 34 & 8 & - & 42 \\
\hline
\end{tabular}

Dari hasil pendataan didapatakan jumlah balita dengan status gizi baik sebanyak 34 anak (81\%), gizi kurang 8 anak (19\%), dan tidak ada gizi buruk. Dapat dilihat bahwa balita yang menderita kurang gizi semua berada diatas usia 12 bulan dengan jumlah terbanyak pada usia 13-24 bulan. Kondisi ini bisa disebabkan karena adanya periode transisi dari masi bayi ke anak, dimana anak mulai belajar mengkonsumsi makanan padat dengan jenis yang beragam. Beberapa permasalahan yang mungkin terjadi seperti anak mengalami kesulitan makan atau tidak tertarik pada makanan rumah. Disisi lain anak sudah mulai berinteraksi lebih banyak dengan lingkungan luar yang mungkin tidak sehat terutama setelah usia 2 tahun. Apabila pola pengasuhan salah terutama dalam pemberian makan anak, maka bisa mengakibatan anak kurang gizi bahkan mengalami penyakit infeksi. Infeksi yang terjadi berulang tidak hanya menyebabkan penurunan berat badan tapi juga menganggu tumbuh kembang anak.

Fakta ini sesuai dengan pernyataan Soetjiningsih (2005) bahwa periode rawan bagi anak adalah usia balita karena mudah mengalami kekurangan gizi dan menderita penyakit infeksi. Disisi lain, tahap balita merupakan golden period untuk masa tumbuh kembang dalam menentukan kualitas anak di kemudian hari untuk menghasilkan sumber daya manusia yang berkualitas. Oleh karena itu, anak yang mengalami kurang gizi pada periode balita bila tidak tertangani dengan baik dapat mengalami kegagalan tumbuh (growth failure) (Dep. Gizi dan Kesmas FKM-UI, 2007).

Hasil pengabdian ini belum menunjukkan faktor penyebab yang lebih spesifik penyebab balita mengalami kekurangan gizi. Oleh karena itu 
diperlukan pengabdian lanjutan dengan melakukan pendataan yang lebih rinci seperti data demografi dan pola asuh balita.

\section{KESIMPULAN}

Pemberian PMT berkualitas penting bagi balita agar tidak mengalami gizi buruk atau kurang. Kegiatan ini dihadiri 42 balita dengan hasil penilaian sataus gizi baik 34 anak (81\%), gizi kurang 8 anak (19\%), dan tidak ada gizi buruk.

\section{DAFTAR PUSTAKA}

Ali, Sadiq Mohammad. 2006. Socioeconomic, Psychosocial, Behavioural, And Psychological Determinants Of Bmi Among Young Women: Differing Patterns For Underweight And Overweight/Obesity. Eur J Public Health, 16(3): 324-330.

Andriani Elisa P, Sofwan I. 2012. Determinan Status Gizi Pada Siswa Sekolah Dasar. Jurnal Kemas, 7 (2): $122-126$.

Dep. Gizi dan Kesehatan Masyarakat FKM UI. 2007. Pedoman Tata

Laksana KEP Pada Anak di RS Kabupaten/Kodya. Departemen Gizi Dan Kesehatan Masyarakat. Jakarta.

Direktorat Gizi Masyarakat Kemenkes RI. 2017. Buku Saku Pemantauan Status Gizi Tahun 2017. Jakarta: Kementrian Kesehatan Republik Indonesia.

Mamhidira, G. 2006. Underweight, Weight Loss And Related Risk Factors Among Older Adults In Sheltered Housing: A Swedish Follow-Up Study. The Journal of Nutrition, Health and Aging, 10(4): 255-262.

Soetjiningsih. 2005. Tumbuh Kembang Anak. Bagian Kesehatan Anak Fakultas Kedokteran Universitas Udayana. Bali. 